\title{
Transatlantica
}

Revue d'études américaines. American Studies Journal

\section{Emily C. Burns, Transnational Frontiers: The American West in France}

James R. Swensen

\section{OpenEdition}

\section{Journals}

Electronic version

URL: https://journals.openedition.org/transatlantica/11786

DOI: $10.4000 /$ transatlantica. 11786

ISSN: 1765-2766

\section{Publisher}

Association française d'Etudes Américaines (AFEA)

Electronic reference

James R. Swensen, "Emily C. Burns, Transnational Frontiers: The American West in France",

Transatlantica [Online], 1 | 2018, Online since 01 September 2019, connection on 03 February 2023.

URL: http://journals.openedition.org/transatlantica/11786 ; DOI: https://doi.org/10.4000/

transatlantica. 11786

This text was automatically generated on 3 February 2023.

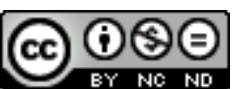

Creative Commons - Attribution-NonCommercial-NoDerivatives 4.0 International - CC BY-NC-ND 4.0 https://creativecommons.org/licenses/by-nc-nd/4.0/ 


\title{
Emily C. Burns, Transnational Frontiers: The American West in France
}

\author{
James R. Swensen
}

\section{REFERENCES}

Emily C. Burns, Transnational Frontiers: The American West in France, Norman, OK:

University of Oklahoma Press, 2018, 230 pages, \$45, ISBN-10: 0806160039

1 Transnational Frontiers has a great opening line. "The American West," writes the author, art historian Emily C. Burns, "is a slippery concept, particularly in international settings." This initial sentence gets to the heart of the challenge of discussing the West, which has long existed as an idea as much as an actual place. It also touches on the ways in which many of the myths of the West were supported and even shaped abroad. As Burns successfully demonstrates, from beginning to end, this is especially true in France where the West was "not a fixed concept but rather a transnational discourse."

2 Burns's text investigates the shifting presence of the West in France during the last decades of the nineteenth and early twentieth centuries, a period, more or less, framed by Buffalo Bill's Wild West shows in and around Paris in 1889 and 1905-1906. At that point in time and in that particular place, the West was, as Burns writes, contingent and context-driven and dependent on "national, cultural and individual identities." Visual representation played a key role in the formation and perpetuation of western tropes and the query at the center of Burns's argument is "how the imagery of the American West participated in building individual and collective mythologies." To answer this question, Burns engages visual imagery in a series of case studies that explore the evolving nature of the West through dialogues and conversations, claims and counterclaims, acts and counteracts.

3 Another key element of Burns's discussion is the "tripartite dialogue" that focuses on the cultural exchange between American, French, and Lakota participants who "performed" the West in France. Indeed, French and American men "played cowboys 
and Indians" and the Native American performers of the popular Wild West shows not only acted out stereotypical roles, but also fought to maintain control over their own representation and movements in Paris, and, by so doing, were able to overcome primitivist types and colonialist overtones. The text also details current events and political uncertainties in France and the United States that shaped these dialogues and played a role in the way visual materials were interpreted.

Although Transnational Frontiers is Dr. Burns's first monograph, it is not her first foray into the field. Through numerous articles and book chapters published over the past few years, she has emerged as an authority on the transatlantic exchanges between the United States and France and, more specifically, on the representation of the West in Paris. This book highlights her talents and abilities as a scholar and writer. It is extensively researched and fully illustrated. Years of exhaustive archival work enrich every page and her arguments are buttressed by detailed footnotes that further map the discourse. The text is approachable and intelligent. Burns's cultural study is enriched by a wide range of disciplines and textual material from a host of academic voices including historians, literary scholars, anthropologists, cultural geographers, and scholars of race and gender, to name but a few. It also benefits greatly from the writings of Native scholars.

While Burns is particularly good at weaving diverse voices into her text, its strength is the way visual materials "participate in larger discursive conversations." She highlights the work of more well-known artists like Rosa Bonheur and Albert Bierstadt, as well as those whose fame has tarnished over the century, like Solon Borglum. Yet, the discussion is not limited to painting or sculpture. Throughout the book the author integrates the so-called "fine arts" with a host of other media. Some of the finer points of the text, in fact, revolve around the discussion of postcards, toy panoramas, Rookwood vases, posters, photographs, and popular illustration. By "reentangling" these objects, she reveals the various and simultaneous ways in which the West was experienced in turn-of-the-century France. In one example, Burns follows the history of a beaded buckskin jacket once belonging to oglala performer Ithúnkasan Gleška (Spotted Weasel), which came into the possession of Joë Hamman, a French Wild West enthusiast who played both Indian and cowboy throughout his life. The unique article of clothing was featured in photographs and in one of the first Westerns, filmed in France, not in the United States. The passage of the jacket from one owner to another and from one medium to the next is emblematic of the ways in which the meaning of objects tied to the West are malleable but continue to reinforce its myths.

Another "reentangling" takes place with the various participants featured in the book. There are, of course, the usual suspects like William F. Cody and Bonheur, an avid admirer of Cody and his performers. Through meticulous research, however, Burns balances these better-known luminaries with a host of others including American artists like Cyrus Dallin and Elbridge Ayer Burbank, and the Native American performers who travelled with Cody on his European tours. By broadening the cast of characters in her narrative, Burns further demonstrates how the myth and lure of the West permeated French society and resonated within a diverse group of individuals.

Both reentanglements are clearly on display in one of Burns's best case studies: the investigation of correspondence between Ištá Ská (Jacob White Eyes), a member of Cody's troop during the 1905-6 European tour, and Falco de Baroncelli, a French aristocrat and Western fanatic. In chapter four Burns details the post and photocard 
exchange that took place between these disparate individuals during Ištá Ská's tour and upon his return to the Pine Ridge Reservation in South Dakota. As rich as any visual material, these seemingly pedestrian objects reveal how the realities of life on the reservation ran headlong into romanticized visions held by individuals like Baroncelli.

One of the most significant contributions of this book, however, is the inclusion of the Native Americans and the Lakota nation, in particular, within Burns's "tripartite dialogue." Understanding how the West was formed in France requires more than simply looking at French and American actors. The broader interaction was not a transnational dialogue, Burns argues, but a multinational engagement. The traveling participants of Cody's troop played an important role in the transmission of culture and were active participants in the construction of the West in France. Clearly the dynamics of power was not equal, but by employing Anishinaabe scholar Gerald Vizenor's notion of "survivance," or continued Native presence and power even under suppression, Burns places Native Americans centrally into the discourse. A key component of returning these individuals to the narrative is returning their names. Thus, Rocky Bear, the popular performer who drew attention everywhere he went in Paris in 1889, is known throughout the text by his rightful name, Íyyan Matho. The same is true for Hinmatóowyalahq'it (Chief Joseph) of the Nez Percé and the Lakota chief ógla Lúta (Red Shirt). By so doing Burns humanizes these individuals and highlights their agency and autonomy. They become more than stereotypes or "simulated Indians," but individuals who were participants in their own politics of identity and "contradictory positions." Burns's inclusion of the Lakota within the discourse is a sizable achievement and should serve as a model for future scholarship. This is especially true in the current cultural and political environment in which the West continues to act as a metonym for the United States and the US president displays an ongoing insensitivity toward Native Americans. ${ }^{1}$

In all, Burns's remarkable book should be required reading for anyone interested in the American West and the formation of the myths associated with it. In its ability to bridge disciplines, Transnational Frontiers not only deepens the discourse but provides an excellent example of art history's ability to create engaging dialogue between textual and visual materials. The West may be a slippery concept but through Burns's insight, it is possible to gain a greater understanding of the ways it and its enduring myths were appropriated to meet the needs of a diverse group of Americans, Frenchmen, and Native Americans. It demonstrates, once again, that the West was to be found, performed, and embraced well beyond the actual American West.

\section{NOTES}

1. Jeet Heer, “Trump Can't Stop Insulting Native Americans," The New Republic, 2018: https:// newrepublic.com/minutes/151118/trump-cant-stop-insulting-native-americans 
INDEX

Subjects: Recensions

\section{AUTHORS}

JAMES R. SWENSEN

Brigham Young University 